Таким образом, потенциал развития экологического туризма в Республике Крым опирается на привлекательность и уникальность разнообразных природных ресурсов, которые в большей или меньшей степени сконцентрированы во всех муниципальных образованиях региона. При этом большая нагрузка туристского потока на Южнобережный и Горный районы Крыма в летний сезон может быть скорректирована привлечением российских туристов перспективой посещения природных объектов также в теплое межсезонье и в других районах Предгорного и Степного Крыма, в которых расположено также большое и разнообразное количество природных объектов. Развитие экологического туризма в муниципальных образованиях, на территории которых они расположены, могут дать дополнительный стимул развитию других направлений туристско-рекреационной сферы, занятости местного населения и поступлений в бюджет, при условии комплексного решения инфраструктурных проблем и создания привлекательного туристского продукта.

Благодарности. Публикаџия подготовлена при финансовой поддержке РФФИи Совета Министров Республики Крымм в рамках научного проекта №19-410-910016 «Механизм устойчивого эколого-экономического развития рекреационной сферы региона: концепциия, факторы, критерии» $* * *$

1. Стратегия социально-экономического развития Крыма до 2030 года. [Электронный ресурс]. URL:http://crimea.gov.ru/textdoc/ru/7/act/352z.pdf

2. Стратегия развития туризма в Российской Федерации до 2035 года [Электронный ресурс]. URL:http://static.government.ru/media/files/FjJ74rYOaVA4yzPAshEulYxmWSpB4lrM.pdf

3. Кузьмина О.М., Пегушина А.А. Выявление и систематизация факторов развития и привлекательности Республики Крым в контексте развития экологического и этнографического туризма // Сервис в России и за рубежом, 2019, Т.13. №5 (87). - C.110-124. DOI: 10.24411/1995042X-2019-10511

4. Воронина А.Б. Типология особо охраняемых природных территорий Крыма по видам рекреационной деятельности // Современные научные исследования и инновации (электронный журнал). 2015. №4. Ч.4. URL:http://web.snauka.ru/issues/2015/04/51299 (дата обращения: 03.09.2019)

5. Подгородецкий П.Д. Крым: Природа. Симферополь: Таврия. 1988. 192 с.

6. Храбовченко В.В. Экологический туризм. М.: Финансы и статистика, 2003. 208 с.

7. Перечень особо охраняемых природных территорий ООПТ России [Электронный ресурс]. URL:http://oopt.aari.ru/

8. ГАУ Республики Крым «Управление особо охраняемыми природными территориями». [Электронный ресурс]. URL:http://ooptrk.ru/2-uncategorised/89-oopt-respubliki-krym

\title{
Aliyeva M.A.g. Minimal draft of insurance analyse of Azerbaijan
}

Azerbaijan National Academy of Sciences (Azerbaijan, Baku)

doi:10.18411/sciencepublic-08-02-2020-11

idsp: sciencepublic-08-02-2020-11

\section{Abstract}

Insurance market have a variety of problems with risk speculation. Insurance companies should obey the risk management rules as defeat problems of long- and short-term risks. Stress and scenario tests give solution for detecting and observing unplanned events in the both of the life and non-life insurance sector. It is like observing space and identifying comet that potential threat for Earth and observing risks among so many and choosing the pioneer threat for insurance spectrum is a must do for all of insurance-based entities. Stress and scenario tests can make eligible to find out main risk perils and used to evaluate the potential effects on an institution's financial condition of a specific event or movement in a set of financial variables.

Keywords: risk, insurance, finance 


\section{Аннотация}

У страхового рынка есть множество проблем со спекуляцией рисками. Страховые компании должны соблюдать правила управления рисками, чтобы избежать проблем с долгосрочными и краткосрочными рисками. Стресс-тесты и тесты сценариев дают решение для обнаружения и наблюдения незапланированных событий как в секторе страхования жизни, так и в секторе общее страхования. Это подобно наблюдению за космосом и выявлению кометы, что потенциальная угроза для Земли и наблюдение за рисками среди столь многих, и выбор первопроходческой угрозы для страхового специалиста - обязательное условие для всех страховых организаций. Стресс-тесты и тесты сценариев могут дать право выявлять основные риски и использоваться для оценки потенциального воздействия на финансовое состояние учреждения конкретного события или движения в наборе финансовых переменных.

Ключевые слова: риск, страхование, финансы

Insurance is an "uncertain business" characterized by competition for premiums that pushes insurers into the unknown [1, p. 1]. It is competition based on risk gaining, vast of premium means such a huge amount of risk in the pool. Beside of this insurance type of risks insurance companies (in some countries, for example in Azerbaijan insurance organizations) have other risks for operating solely in the finance market as financial institution that companies give financial services. The insurance industry is as much in the business of uncertainty as it is in risk, with notions of quantification and actuarial principle increasingly evaporating in an ever more competitive, vibrant and amorphous insurance market [1, p. 15]. The whole quantification and actuarial principles make scurry rush under risk probability of harm. Insurance companies face numerous risks arising from the insurance industry itself and financial ones on a daily basis, as well as risks arising from insurance company operations in financial sphere or regular operations, such as placing available funds, fulfilling obligations, harmonizing resources with insurance premiums and the placement of free funds for the future deeds. are facing.

Insurance writings in common appeal several types of risk that insurance companies

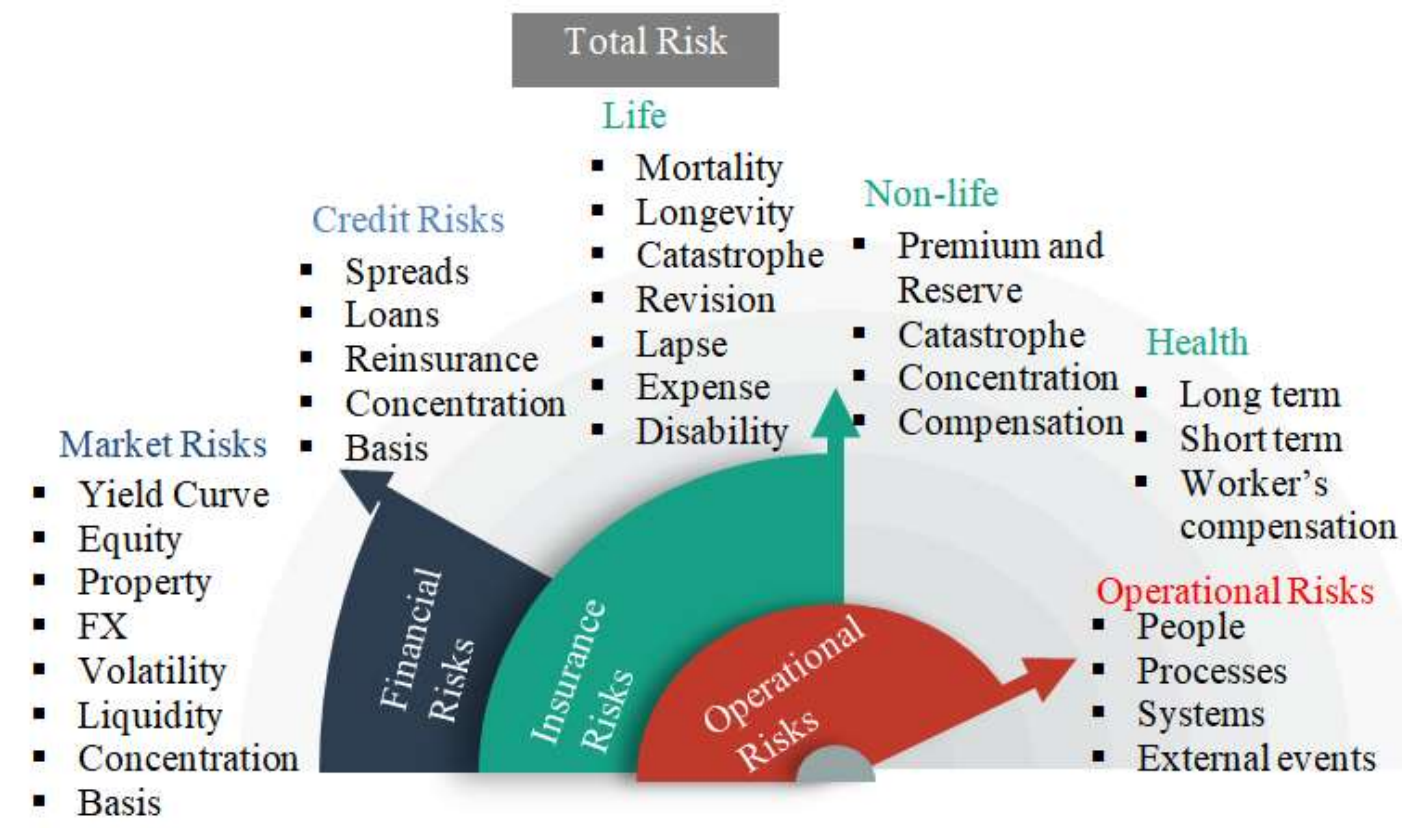

Figure 1. Risk types of insurance companies. Source: Based on source it is created by author [3, p. 5]

As insurance industry sets up a significant part of the finance system particularly in developed countries, it is specialized in the field of different risks. Common practice for insurance companies due to increasing funds invest several financial assets in order to utilize 
the insurance premiums they have collected. Therefore, it is unavoidable that insurance companies stand face to face with financial risks. Among the common risks other than insurance transactions that life insurance and pension companies are exposed to, there are financial risks such as interest rate risk, credit risk, liquidity risk, exchange rate risk. In addition, market risk, group risk, operational risk, modeling risk, and regulatory re-stictions risk are also significant when it comes to insurance companies. Financial risks involve two major factors. The first one is the deteriorations in the macroeconomic capacity as a result of political or economic crises both in national and international settings [4]. As these kinds of risks arise from an imbalance in the system and they are also known as market risks or they can be classified as systematic risks. The second ones classified as unsystematic risks which commonly arise from the inner structure of a company and are defined by factors such as management quality, integrity of the financial structure and the skills of being competitive. Operational risks are totally unsystematic and insurance risks include both systematic and unsystematic types, however financial risks are mainly systematic.

Table 1

The degree of loss for types of insurance

\begin{tabular}{|c|l|c|c|c|}
\hline $\mathbf{N} N$ & \multicolumn{1}{|c|}{ Insurance types } & $\begin{array}{c}\text { Insurance } \\
\text { premiums } \\
\text { (MM, AZN) }\end{array}$ & $\begin{array}{c}\text { Insurance } \\
\text { claims (MM, } \\
\text { AZN) }\end{array}$ & $\begin{array}{c}\text { The degree } \\
\text { of loss (\%) }\end{array}$ \\
\hline $\mathbf{1}$ & Health insurance (voluntary insurance) & $\mathbf{8 7 , 0 6}$ & $\mathbf{5 9 , 4 8}$ & $\mathbf{6 8 , 3 3}$ \\
\hline $\mathbf{2}$ & $\begin{array}{l}\text { Compulsory civil liability insurance of } \\
\text { motor vehicles owners }\end{array}$ & 95,44 & 53,51 & 56,06 \\
\hline $\mathbf{3}$ & Life insurance & 253,94 & 93,37 & 36,77 \\
\hline $\mathbf{4}$ & Motor vehicles insurance & 28,45 & 9,57 & 33,65 \\
\hline $\mathbf{5}$ & $\begin{array}{l}\text { State personal compulsory insurance of } \\
\text { military servants }\end{array}$ & 16,83 & 5,01 & 29,77 \\
\hline $\mathbf{6}$ & Insurance of agricultural animals & 2,04 & 0,5747 & 28,17 \\
\hline $\mathbf{7}$ & Insurance of agricultural products & 0,6398 & 0,1803 & 28,17 \\
\hline $\mathbf{8}$ & $\begin{array}{l}\text { Compulsory civil liability insurance for the } \\
\text { use of real estate }\end{array}$ & 0,2994 & 0,0837 & 27,96 \\
\hline $\mathbf{9}$ & Insurance of citizens traveling abroad & 3,76 & 0,7495 & 19,94 \\
\hline $\mathbf{1 0}$ & $\begin{array}{l}\text { Compulsory state insurance of employees of } \\
\text { judicial and law enforcement bodies }\end{array}$ & 13,34 & 2,01 & 15,06 \\
\hline $\mathbf{1 1}$ & Compulsory real estate insurance & 30,36 & 4,03 & 13,26 \\
\hline $\mathbf{1 2}$ & $\begin{array}{l}\text { Civil liability insurance of air vehicle } \\
\text { owners }\end{array}$ & 4,38 & 0,5669 & 12,94 \\
\hline
\end{tabular}

Source: Based on source it is created by author [5, year 2018]

The degree of loss:

$$
\left(\frac{\text { Insurance claims }}{\text { Insurance premiums }}\right) * 100
$$

Return on insurance premiums:

$$
\left(\frac{\mid \text { Insurance claims - Insurance premiums } \mid}{\text { Insurance premiums }}\right) * 100
$$

The degree of loss and return on insurance premiums can be eligible forms for better understanding general degree of risk possibility in different insurance fields. Degree of loss could show how much of speed in leverage between insurance premiums and claims. Health insurance from general and life insurance from life types are enough speedy in the insurance transactions.

Return on insurance premiums also show that how much of claims formed by the collected premiums. It could dictate with clear numbers in quarterly reports. If in the specific insurance type, such as passenger transportation insurance in Azerbaijan, has no claim then it shows apricated value of it.

A number of issues have been brought to well that Solvency II is the best option in the insurance fields and let the recognizing the importance of regulatory and compliance issues in 
the insurance industry, operative risk management tools can help organizations balance regulatory compliance needs, demands, and requirements with business efficiency and turn compliance into a business strategy, improving the risk-based efficiency of compliance operations.

FIMSA is a public legal entity that regulates and supervises participants of the securities market, investment funds, insurance and credit organizations (banks, non-banking credit organizations and postal operators) and payment systems, and ensures transparency and flexibility in its supervision. FIMSA can adopt legal acts regulating the financial markets, issue and revoke the licenses of the participants of the financial markets, and carry out inspections of participants.[6] As doing stress tests should be awared of in Azerbaijan insurance market mainly regulated by government organizations. It should be taking to account that security and insurance market regulations depend on international conditions and their flow to Azerbaijan. Azerbaijan government can change the policy in these fields as the change in the international triangle of money, debt and credit. Stress tests for avoiding bankruptcy, insolvency should embrace policy of government regulations and macroeconomic situations and as well as company coverage on different services and scope of country, reputation.

Table 2

Objectives of insurance stress testing

\begin{tabular}{|c|c|c|}
\hline \multirow{4}{*}{ 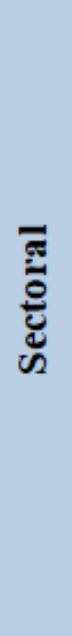 } & Sector resilience & $\begin{array}{l}\text { Assess losses across the Azerbaijan insurance industry to severe, } \\
\text { conceivable scenarios to inform FIMSA's view of sector resilience. }\end{array}$ \\
\hline & $\begin{array}{l}\text { Systemic risks/ } \\
\text { Sectoral behaviors }\end{array}$ & $\begin{array}{l}\text { Assist in understanding the extent to which individual companies make } \\
\text { business decisions that are appropriate for the company but, taken } \\
\text { across the entire sector, may result in strongly acverse outcomes (e.g.: } \\
\text { all switching into one asset class). }\end{array}$ \\
\hline & $\begin{array}{l}\text { Counterparty } \\
\text { dependencies }\end{array}$ & $\begin{array}{l}\text { Identify the extent to which the sector relies on a concentration of } \\
\text { reinsurers or jurisdictions following an extreme scenario. }\end{array}$ \\
\hline & $\begin{array}{l}\text { Exploratory risks/ } \\
\text { horizon scanning }\end{array}$ & $\begin{array}{l}\text { Assist in exploring andraising industry debate around emerging risks } \\
\text { to understand how firms are responding e.g. in relation to } \\
\text { climate change or cyber risks }\end{array}$ \\
\hline
\end{tabular}

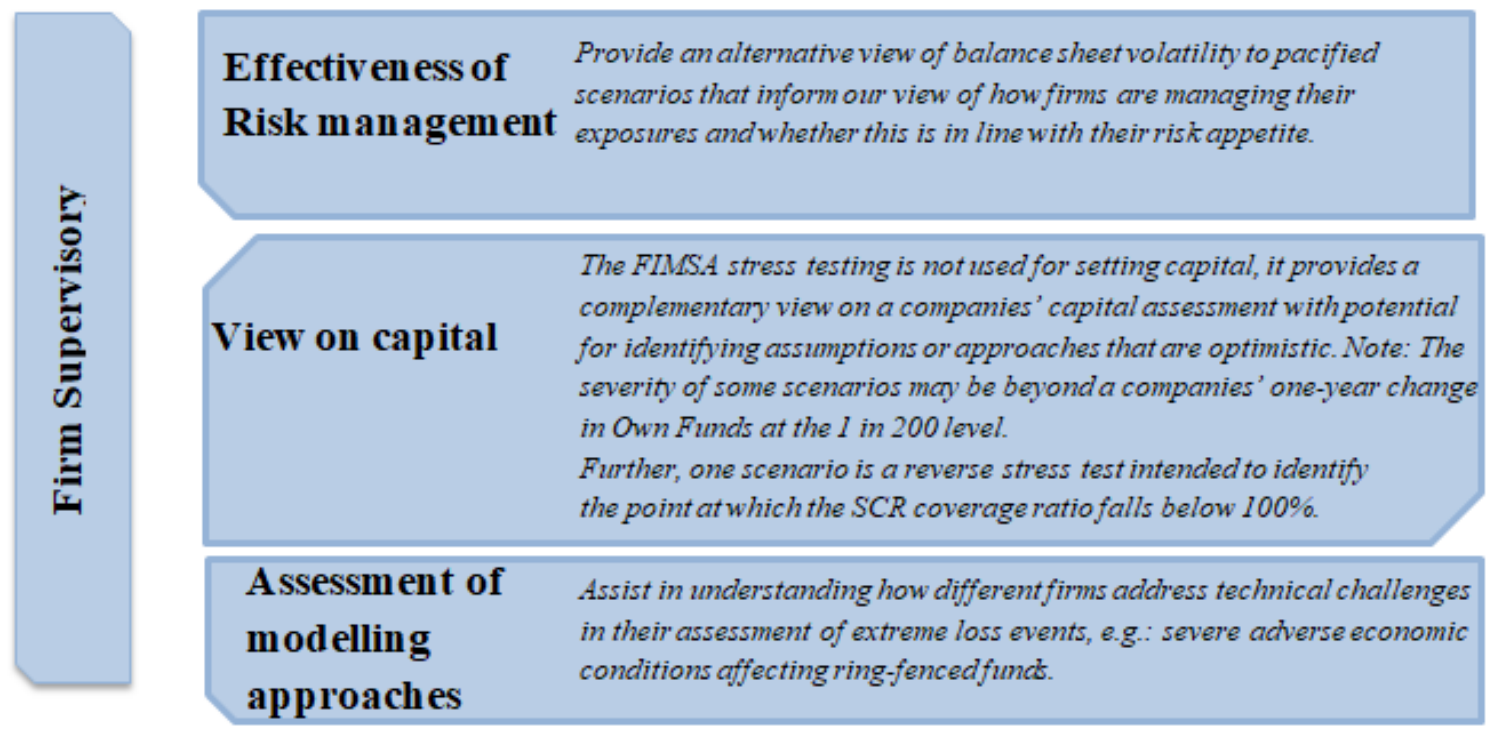

Source: Based on source it is created by author [6, p. 2] 
Structure of the life insurance stress test consists of two parts:

- Sections A and B contain the essential stress tests: a downturn in the economic environment and a set of three life insurance specific scenarios, for example, a parallel downward shift in risk free interest rates, an increase in longevity expectations, fall in mortality rates and etcetera.

- Section $C$ is not a stress test; instead it is designed to gain data how different insurance companies are managing difficult to measure risks. For life insurers it covers a climate change exploratory exercise. [7, p. 3] scenarios.

Insurance are requested to assess their year-end balance sheet against the following

Structure of the general insurance stress test consists of two parts:

- Sections A and B comprise the principal stress tests: a decline in the economic environment and a set of six possible scenarios: four natural catastrophe scenarios, a separate claims inflation scenario as well as a new cyber underwriting loss scenario.

- Section $\mathrm{C}$ is not a stress test as life insurance; instead it is designed to get data relating to how different insurance companies are managing difficult to measure risks. It comprises a new climate change exploratory exercise and repeats a previous year data request for acquaintances that whould allow the FIMSA better understand the impact of potential losses by various sectors of the economy. [8, p. 3]

Stress tests and scenario analysis should be kept under the general conscious of countrie and region business ethics, their special problems and especially, market demand of insurance provisions. Each market has opportunity to regulate itself by its invisible and spontaneous vital tools.

$$
* * *
$$

1. Mirjana M. Ilić, Veselin Avdalović and Milica D. Obadović (2011) "Development of model for insurance risk management and its application to insurance companies operating in the Serbian market", Journal of Business Management and Economics, 2(6), p. 223-228;

2. Ericson R, Doyle A (2004). Uncertain Business: Risk, Insurance, and the Limits of Knowledge, University of Toronto Press, Scholarly Publishing Division

3. https://www.moodysanalytics.com/risk-perspectives-magazine/stress-testing-europe/principles-andpractices/stress-and-scenario-testing-how-insurers-compare-with-banks

4. Yildirim, I. (2015). Financial Risk Measurement for Turkish Insurance Companies Using VaR Models. Journal of Financial Risk Management, 4, 158-167. http://dx.doi.org/10.4236/jfrm.2015.43013

5. https://www.fimsa.az/menu/sinifler-uzre/118

6. https://www.bankofengland.co.uk/-/media/boe/files/prudential-regulation/letter/2019/life-insurancestress-test-2019-scenario-specification-guidelines-and-instructionsdraft.pdf?la=en\&hash=2B68B1095416387FA12164B743E5D1C678231DD3

7. Bank of England, Prudential Regulation Authority "Scenario Specification, Guidelines and Instructions" draft for feedback from participating firms - life insurance

8. Bank of England, Prudential Regulation Authority "Scenario Specification, Guidelines and Instructions" draft for feedback from participating firms - nonlife insurance 